This item was submitted to Loughborough's Research Repository by the author.

Items in Figshare are protected by copyright, with all rights reserved, unless otherwise indicated.

\title{
Fostering sustainable performance in services through systems thinking
}

PLEASE CITE THE PUBLISHED VERSION

https://doi.org/10.1080/02642069.2018.1551371

\section{PUBLISHER}

(c) Taylor \& Francis

\section{VERSION}

AM (Accepted Manuscript)

\section{PUBLISHER STATEMENT}

This is an Accepted Manuscript of an article published by Taylor \& Francis in The Service Industries Journal on 3 December 2018, available online: http://www.tandfonline.com/10.1080/02642069.2018.1551371.

\section{LICENCE}

CC BY-NC-ND 4.0

\section{REPOSITORY RECORD}

Jaaron, Ayham A.M., and Chris Backhouse. 2018. "Fostering Sustainable Performance in Services Through Systems Thinking". Loughborough University. https://hdl.handle.net/2134/36186. 


\title{
Fostering sustainable performance in services through systems thinking
}

\author{
Ayham A.M. Jaaron ${ }^{\mathrm{a}}$ \& Chris J. Backhouse ${ }^{\mathrm{b}}$ \\ ${ }^{a}$ Industrial Engineering Department, An-Najah National University, Nablus, West Bank, \\ 97200, Palestine; \\ ${ }^{b}$ Wolfson School of Mechanical, Electrical and Manufacturing Engineering, \\ Loughborough University, Loughborough, LE11 3TU, UK
}

This paper aims to investigate the impact of designing service operations using the systems thinking approach on the sustainable performance of service organisations. Data was collected from a survey conducted with 183 service organisations that have implemented the systems thinking approach. Using Structural Equation Modelling, the results confirmed that using the systems thinking approach has a significant impact upon the environmental and social performances but has no direct effect on the economic performance of such organisations. The analysis also indicated a statistically positive relationship between environmental and economic performances and between social and economic performances, but not between environmental and social performances, thus suggesting that the dimensions of sustainable performance should not be viewed as being equally weighted. This study shows that the systems thinking approach ensures that the service system design is directly linked with enhanced environmental and social benefits while indirectly contributing to economic benefits.

Keywords: sustainability, sustainable performance, service management, service operations, TBL of sustainability, systems thinking, service industries, sustainable design.

\section{Introduction}

The attention to ecological issues resulting from services has been gaining prominence, as western economies are increasingly becoming service-oriented (Rosenblum et al., 2000; Junnila, 2006a; Cocca and Ganz, 2015; Prendeville and Bocken, 2017). According to Zhang et al. (2012), the service sector consumes substantial quantities of energy and produces increasing amounts of emissions and wastes. For example, the climate change impact of service sector in the United States is estimated to be almost as 
high as that of manufacturing sector (Rosenblum et al., 2000). This environmental impact of services has been further asserted by several previous studies such as Junnila (2006b), Jo et al. (2015), and Angelia and Suryaningsih (2015). With regard to these considerations, the demand for sustainable service operations designs that meet customers' changing needs while considering environmental impacts is overwhelming (Evans et al., 2007; Roos and Agarwal, 2015). This sustainable service concept is defined by Chowdhury and Quaddus (2016) as the process of integrating service design components and service delivery operations in order to achieve service organisations' sustainability goals. However, the adoption of sustainable practices within service departments constitutes a major operational challenge (Chou et al., 2012; Manz et al., 2015; Prendeville and Bocken, 2017; Zhang et al., 2012). This is because both the implementation and practice of sustainable performance are complex, multidimensional, and dynamic in nature (Nguyen and Bosch, 2013). In this study, organisational sustainable performance is defined as a dynamic process that requires achieving shortterm performance (financial earnings without compromising long-term performance (considering social and environmental impacts of the work) (Gadenne et al., 2012). In principle, sustainable performance tends to connect ecological, social, and economic issues of an organisation across political, temporal, and spatial dimensions that cannot be addressed and tackled in isolation (Chou et al., 2012; Longoni and Cagliano, 2016; Martínez León and Calvo-Amodio, 2017). Williams et al. (2017) strongly emphasise that the successful implementation of sustainable practices requires the adoption of a multidisciplinary systemic lens to grasp the interconnectivity of ecological, social, and economic dimensions of organisational sustainability. As a result, each of these dimensions is a system on its own that is also an integral part of a larger organisational complex system. The magnitude of each dimension of sustainable performance can 
change when it interacts with the other two dimensions. Hence, a traditional reductionist approach that is based on silo working of dimensions of sustainability will show its inability to address sustainability issues in organisations (Adetunji et al., 2003; Nguyen and Bosch, 2013; Williams et al., 2017). Generally speaking, Gray (2010) stated that sustainable performance is a system-based concept that can only be materialised when looking at the systems as a whole. This would firmly suggest that a systems thinking approach of looking at dynamic interactions within and across the dimensions of organisational sustainable performance is needed to achieve sustainable performance in the service sector (Mutingi and Mbohwa, 2014; Waller et al., 2015). According to Arnold and Wade (2015), systems thinking can be defined as 'a set of synergistic analytic skills used to improve the capability of identifying and understanding systems, predicting their behaviors, and devising modifications to them in order to produce desired effects. These skills work together as a system.' Ignoring the adoption of a systems thinking approach in organisations has been depicted by several authors as the main impediment to sustainable performance (Bell and Morse, 2005; Fiksel, 2012; Martínez León and Calvo-Amodio, 2017; Smith, 2011). It is as acknowledged by Starik and Kanashiro (2013) that through the application of systems thinking, it would be possible for service organisations to articulate a method that is capable of identifying organisational actions that can directly impact the natural environment. Despite this fact, empirical studies investigating the impact of systems thinking on sustainable performance of service organisations, considering the three dimensions of sustainability, have been scarce. Furthermore, to the best of the author's knowledge, previous research linking the virtues of a systems thinking approach to sustainable performance, in a service context, is mainly focused at the conceptual level (Smith, 2011; Waller et al., 2015; Williams et al., 2017; Zhang et al., 2012), without providing substantial empirical 
support to these links. Arising from this, this paper aims at closing the aforementioned gap by empirically investigating the impact of applying an innovative system thinking approach for service operations design on the Triple Bottom Lines (TBL) of service organisations' sustainable performance (i.e. environmental, social, and economical). The innovative systems thinking approach adopted in this study is introduced by Seddon (2003) in his book "Freedom from Command and Control: A Better Way to Make the Work Work'. It is centered on three core elements of interrelationships of employees interaction and social exchange (both within their teams and between organisational parts), dynamics of the organisation (that requires a significant amount of coordination, and power delegation to team members), and wholeness of the organisation (where departments are dependent on each other and the whole to guarantee the interconnectedness of people) (Jaaron and Backhouse, 2016; Jackson et al., 2008; Seddon, 2008). The study is focused on post-the systems thinking implementation in service organisations. Therefore, the following research question has been posed in this paper:

RQ. To what extent is the systems thinking approach for service operations design related to the TBL of sustainable performance in a service setting?

To answer this research question, a specially designed survey was performed to collect field data from UK-based service organisations that have adopted the systems thinking approach into their service operations design. The survey was developed based on literature reviews in the sustainable operations and systems thinking research areas and based on previous several case studies conducted by authors of this paper. The use of survey instrument was supported by the work of several authors in the area of sustainable operations and sustainability management, and was deemed powerful in gaining empirical evidence in this area (Bamgbade et al., 2017; Blok et al., 2015; de 
Freitas et al., 2017; Longoni and Cagliano, 2016). This research seeks to investigate the linkage between the application of systems thinking approach to service operations and enhancing sustainable performance in service industries.

This paper contributes to theory by, first, providing evidence that systems thinking approach, in a service setting, ensures the service system design is directly linked with enhanced environmental and social benefits while indirectly contributing to the economic benefits. Second, it shows that the environmental and social dimensions of the TBL of sustainable performance in services are preconditional for the economic performance. Third, the research also shows that systems thinking approach directly creates a social system where both employees and customers build mutual trust, common meaning, and shared values that can be used to improve consumption pattern of service resources.

The paper is further organized as follows. The next section presents the literature review conceptualizing sustainable performance and systems thinking, and connecting systems thinking with the TBL of sustainability. This is followed by the research methodology section outlining sampling and data collection methods. Next, data analysis and results are explained. This is followed by discussing the results. Finally, research conclusions including theoretical and managerial implications, research limitations, and future research work are highlighted.

\section{Conceptual Background and Hypotheses}

\section{Organisational Sustainable performance}

As discussed earlier, sustainable performance is increasingly becoming a pressing topic in the field of service design and delivery (Chou et al., 2012; Chowdhury and Quaddus, 2016; Manz et al., 2015). Although the concept of sustainable development emerged in 
the early 1970s, the term was first formally coined at a global level in 1987 with the Brundtland report (Nations, 1987). In this report, sustainable development was defined as "development that meets the needs of the present without compromising the ability of future generations to meet their own needs." Although this definition has helped in promoting the concept throughout the globe, the need for a more transparent definition became apparent due to the narrow scope of the current model that fails to show specific dimensions for achieving sustainable development. For this purpose, Adetunji et al. (2003, p. 1) defined sustainability as "the integration of the environmental, social, and economic systems to improve the quality of life within earth's carrying, regenerating and assimilating capacity." This definition entails the set of universal actions, and inherent interrelationships, that are designed to drive the TBL around global environmental protection, social responsibility, and economic growth of countries (Arnold, 2017; Mutingi and Mbohwa, 2014). This has precipitated increased stakeholders' demands on organisations to manage actions directed at achieving sustainable corporate performance (Gadenne et al., 2012). In response to this situation, many organisations have introduced several sustainable performance practices that target the three dimensions of organisational TBL (Chou et al., 2012; Chowdhury and Quaddus, 2016). However, the three dimensions of TBL also include other issues that must be considered in an integral way (Zhang et al., 2012; Starik and Kanashiro, 2013). For example, Marques et al. (2015), in their study of sustainable water services, asserted that governance issues (e.g., transparency, customers' participation in decision-making processes, efficiency of those decisions, and quality of accountability) encompass an important element in dimensions of sustainability. Also, Seghezzo (2009) argued that sustainability could be better understood in terms of five different dimensions; "spatial" dimension which contains the three dimensions of space, "Permanence" is the fourth 
dimension of time, and human resources represents a fifth dimension. Further, Murray et al. (2009) also propose five dimensions of economic, environmental, social, technical and human health dimensions to understand sustainability. However, it is widely supported that all of the above derivative dimensions of sustainability are included in the three dimensions of TBL (Marques et al.,2015; ), and that defining sustainability as the three dimensions of TBL is one of the most used definitions (Adetunji et al., 2003; Marques et al.,2015; Arnold, 2017). For these reasons the three dimensions of TBL have been adopted in this study.

\section{Service Design and Sustainable performance}

Generally speaking, service design is the application of mechanisms and tools that solve problems through a service response (Prendeville and Bocken, 2017). According to Mog (2004), service design methodologies must consider how a service can adapt to changes in the external environment. This capability for adaptation can then be exploited to mitigate environmental effects and create economic benefits. Thus, it is evident that service design activities and mechanisms can be employed to foster the sustainable performance of organisations (Chou et al., 2012). However, a service design can only contribute to sustainable performance if it can minimise resource consumption to protect the environment, fully meet human needs, and generate economic value for an organisation (Martínez León and Calvo-Amodio, 2017; Zhang et al., 2012).

This concept of sustainable service design requires striking a balance between the dimensions of the TBL. Several recent scholars, such as Etzion (2007), Russo and Minto (2011), and Longoni and Cagliano (2016) focused on traditional management theories, such as the resource-based view, organisational behaviour, and competitive strategies. Although these studies provided significant direction to sustainable

performance research, they did not explicitly reveal the necessity of connecting 
organisations with the social-ecological systems in which they are nested. In response to this oversight, Williams et al. (2017) suggested that 'systems thinking provides an antidote to such silos, as it offers a more holistic lens to examine the role of corporations within social-ecological systems' (p. 867).

However, despite the growing importance of systems thinking in research related to organisations' sustainable performance, the urgent call for more empirical research has not been sufficiently answered (Davis and Stroink, 2016). In the literature review presented below, the concept of the systems thinking approach is integrated with the TBL of sustainable performance to develop hypotheses regarding the relationship between these two complex constructs.

\section{Characterising Systems thinking}

Although there is no consensus on what systems thinking actually is, the concept can be understood based on two widely endorsed constructs: holistic thinking and relational thinking (Lezak and Thibodeau, 2016). Holistic thinking involves a comprehensive view of complex systems that calls for building an understanding of the interrelationships between various parts in the system (Botla, 2009; Cabrera et al., 2008). This whole-system view suggests that a system is composed of subsystems and belongs to a larger system in which it is nested. On the other hand, relational thinking is the process of focusing on the causal relationships between parts of the system (Fiksel, 2012; Smith, 2011). This approach makes visible the unique properties of systems and allows for easier communication and control to adjust system performance in the face of imbalance (Adetunji et al., 2003).

This dynamic process and co-evaluation of a system view, represented by the relational aspect of systems thinking, is consistent with the concept of complexity theory (Davis and Stroink, 2016). According to complexity theory, organisational 
systems are complex and adaptive systems in which the individual parts and collective behaviour constantly evolve (Missimer et al., 2017). Therefore, the importance of systems thinking, in the context of this paper, is manifested in the fact that it is a means of better comprehending and solving complex socio-ecological dilemmas (Bosch et al., 2007).

Gregory (2007) asserted that a reductionist view of a system is inappropriate for adaptability of the system to external pressures, as it is based on silo working, which limits necessary interaction between the parts of a system. Similarly, Ackoff (1981) explained that managing system parts without understanding their interactions causes the system to lose its essential properties and stakeholders to face unintended consequences. Therefore, if a complex context, such as sustainable service operations, is viewed in this reductionist way, the discontinuous forces of silo working would prevent achievement of sustainable performance (Nguyen and Bosch, 2013; Smith, 2011). In fact, the systems thinking approach is of great value to sustainable performance because it considers the dynamic interconnections between the network of actors in economic, social, and ecological systems. Based on these interconnections, organisations activate dependence on larger and smaller internal systems to create value, such as better allocation of human and material resources and more effective support for ecological issues (e.g., waste and emissions reduction) (Winn and Pogutz, 2013). These interconnections are an essential part of the systems thinking approach for service operations design as contributed by Seddon (2003). A detailed account of this approach is reported in the work of Seddon $(2003,2008)$ and also in the work of Jackson et al. (2008), as explained below. 


\section{Seddon's systems thinking approach for service operations design}

Seddon's systems thinking approach articulated a structured process in which service operations are built around customer demands rather than around the functional hierarchies of an organisation (Jaaron and Backhouse, 2016; Jackson et al., 2008). According to Seddon (2003), the systems thinking approach facilitates a culture characterised by the formulation of self-managing teams in order to deliver what the customer wants. For this purpose, front-line employees from the workplace itself are chosen to formulate these self-managing teams, as they are most knowledgeable about how a service can be delivered based on customer needs (Jackson et al., 2008). From a systems point of view, self-managing teams are encouraged to understand the nature of customer demands through the utilisation of feedback loops ( Williams et al., 2017). According to Walker and Salt (2006), feedback loops are 'the secondary effects of a direct effect of one variable on another, they cause a change in the magnitude of that effect' (p. 163). This feedback from the external environment can lead managers to think in terms of service realities to identify opportunities for systems adaptation and transformation (Jaaron and Backhouse, 2016). This response is very relevant to sustainable performance, as managers can exploit feedback to improve indicators of sustainable progress. However, failing to make sense of feedback loops causes the service systems to lose proper decision-making ability to respond to system-changing events, including those related to sustainable performance (Whiteman et al., 2013). In any case, the flow of customer feedback and demands, at all points of contact, must be studied over a considerable period of time in order to derive meaningful insights. As the team pursue this logic, they learn about the main purpose of the service system from the customer point of view, and about different frequencies of demands that the service system has to respond to (Jackson et al., 2008). This will also allow categorisation of 
customer demand into two types: 'value' and 'failure' demands. Value demands are defined as those demands that the service department has been established to serve and are of value to customers (Marshall, 2010; Pham and Jaaron, 2017). Failure demands, on the other hand, are defined as those demands caused by a failure to do something right for the customer (Seddon, 2008). According to Jaaron and Backhouse (2017), the main causes of failure demands are lack of necessary information and/or supporting operations in the workplace. Customer demand analysis, this way, will allow understanding customer demand in customer terms: what matters the most to customers, and what they really expect from the service system at all levels including demands related to environmental protection and customer social benefits (Pham and Jaaron, 2017; Seddon, 2008). However, as soon as the purpose of the service system, from a customer perspective, is defined, the interconnections between service organisation's parts become the focus to deliver that purpose (Jackson et al., 2008). Since value demand is considered as the agreed measure of what matters to customers, the selfmanaging teams start redesigning traditional service operations, to significantly reduce failure demands. According to Jaaron et al. (2014), reduction of repeated customer contacts and, thus, failure demands have the potential to increase material efficiency in service operations. This will, ultimately, help in delivering services with least energy utilization and, hence, improve environmental performance of the service. However, redesigning service operations is conducted through mapping the flow of work from the initial receipt of a demand to completion; showing all of the various steps and decision points in the flow, including waste identification (Dunnion and O'Donovan, 2014; Marshall, 2010). In this important stage, all related organisational policies, rules, and budgetary requirements, also known as system conditions, are considered. It is particularly important, at this stage, to take into consideration the inputs required from 
all internal organisational units to deliver the demand during the first contact of the customer (Gibson and O’Donovan, 2014; Jaaron and Backhouse, 2017). To help maintain these achievements, customer demand is continuously analysed to increase team members learning in the service system, as this will be the only guarantee to increase employees' capability to handle demand uncertainty (Marshall, 2010). Further, continuous demand analysis increases demand predictability and facilitates organisational resources' availability and readiness; thus reducing the chance of errors and enhancing employee-customer communication (Dunnion and O'Donovan, 2014; Gibson and O’Donovan, 2014). Demand predictability has also been linked by Jaaron and Backhouse (2011), Jackson et al. (2008), and Seddon (2008) with handling customer demands by the least number of employees, usually one, and thus little gap is left for duplicating the work by other employees or departments. This ability of processing customer demands one stop dramatically reduces the repetition of customer contacts, which keeps demand queues short, and eventually allowed for resource savings (Marshall, 2010).

In this systems thinking approach, team members training is not the focus in the preparation process for this kind of job; it is actually educating employees on "why" a failure happens and then supporting them to find ways to eliminate it from the system. For this purpose, service senior managers' role changes from command-and-control to helpers and supporters. Top managers are expected to be closer to their employees to help them when necessary (Jaaron and Backhouse, 2011; Jackson et al., 2008; Seddon, 2008). In fact, this role change of top management can influence different ingredients of the service systems such as better execution of operations improvement, promoting ethics of workplace, and increasing effectiveness of communication style (Boiral et al., 2014). According to Williams et al. (2017), this has tremendous positive impacts on 
sustainable performance of organisations. Of particular importance here is the ethical behaviour of workplace that may drive transformational change of resources' consumption methods and cleaner production of services (Painter-Morland, 2008). In addition, top management support to sustainable production of services helps employees to quickly adapt to complex systems dynamics to implement necessary operational changes (Wong et al., 2011).

\section{Systems thinking and environmental performance}

At an environmental performance level, systems thinking has been found to create an organisation that is able to respond to feedback from external stakeholders on its environmental performance (Jaaron and Backhouse, 2016; Lezak and Thibodeau, 2016). It is as posited by Seddon (2008), the application of systems thinking in service operations effectively engages the organisation with external environment, particularly customers, to improve existing methods and internal capabilities. According to Williams et al. (2017), organisations adopting systems thinking approach into business operations design, including service operations, can improve organisation's sustainability indicators through feedback loops with other actors in the external environment. In response to external feedback, the organisation can adapt or transform its internal systems and operations to mitigate environmental impacts (Folke et al., 2010). Moreover, complex adaptive systems using systems thinking lens are able to restructure itself or, in other words, self-organise (Ashton, 2009). Self-organisation is enabled when the environmental system is out of equilibrium, thus, an internal shift in organisational processes is required. Manring (2014) has positively associated this ability of a system with achieving sustainability. The constant adaptation to complex feedback loops, warranted by interconnectedness of subsystems, facilitate the emergence of environmental problems solving through better information flows and 
improved decision making processes (Dougherty and Dunne, 2011). One example of systems thinking in creating internal shift in service processes is the development of strategies for reducing resources consumption through redesigning service operations in the most effective way (Jaaron et al., 2014). This reduction of resources consumption resulting from systems thinking strategies has been described by Fiksel (2012, p.140) as "a necessary step toward decoupling resource consumption from economic growth, and thus achieving a sustainable future". In short, the prevailing notion here is that these offerings of systems thinking (such as self-organising teams and adaptive capacity) have the potential to create a service operations design that can react to environmental performance changes and can also reduce resources depletion; including increasing resources efficiency in operations. The above presented relationships have, therefore, allowed for the articulation of the following hypothesis:

H1. The adoption of systems thinking approach in service operations design is positively related to the environmental performance of service organisations.

\section{Systems thinking and social performance}

From a social dimension, sustainable systems depend on social networks within their human capital to generate governance mechanisms that control human behaviour of protecting and restoring environmental resources (Fiksel, 2012). According to Chou et al. (2012), systems thinking approach has the capability of connecting social networks (i.e. customers and employees) to enhance the remaining two dimensions of sustainability (i.e. environmental and economic), and to simultaneously improve human well-being through sets of behavioural changes (Smith, 2011). In this sense, behavioural changes are seen as a necessary ingredient for sustainable performance because employees' behaviour aggregates to drive systems dynamics in business and society (Marcus et al., 2010). As a consequence, systems thinking has been found to increase 
employees' confidence in problem-solving ability due to direct employees' engagement with emergent events, their connections with each other, and increased employees' awareness of the connected parts of the system they operate (Seddon, 2003; Smith, 2011). Subsequently, systems thinking has the potential to create a working place that is largely driven by shared interests, information, identity, processes, and, thus, competencies (Jaaron and Backhouse, 2017). These virtues of the systems approach establish systems, especially loosely coupled ones such as services, around shared values and meaning at the level of employees, as well as other customers involved (Morgan, 2005). In this context, achieving sustainable practices are, in fact, dependant on the values of all individuals acting in the organisational system, including those customers located outside the boundaries of the organisation, through new forms of interaction that may lead to transformation of consumption patterns (Arnold, 2017; Williams et al., 2017). Furthermore, systems thinking suggests that responsibility is shared among all personnel and that top managers role is shifted from command-andcontrol to supporters (Jaaron and Backhouse, 2016; Manz et al., 2015). It is as posited by Painter-Morland (2008), systems thinking leadership possess extraordinary capabilities and a holistic view on complexities of the embedded systems, and that is what sustainability senior managers require. The ability of a top manager to maintain long term focus and reconcile different views from different parts of the system, through decentralised decision making processes, save available resources and yields sufficient benefits for customers (Williams et al., 2017; Wong et al., 2011). In a service setting, Manz et al. (2015) asserted that building a more organic service system, based on a systems thinking approach, creates a service where customers are viewed as an extended part of the service system; that is creating a customer-centric service. This approach enlists customers to participate in the process of service production along with 
internal employees, thus, economises on available resources and enhances fulfilling customer needs (Jaaron et al., 2014); ultimately achieving numerous benefits for customers and higher levels of satisfaction (Jaaron et al., 2014; Manz et al., 2015; Mutingi and Mbohwa, 2014). However, several authors suggest that systems thinking is also compatible with other social benefits and offerings for employees (Martínez León and Calvo-Amodio, 2017; Missimer et al., 2017; Morgan, 2005; Williams et al., 2017). For example, Missimer et al. (2017) explained that adaptive capacity of systems thinking allows for both individual and institutional flexibility and learning to deal with complex situations and changes. According to authors, learning can happen when effectively reacting to new changes, thus, learning from experiences. Additionally, Jaaron and Backhouse (2011) found that systems thinking creates a learning organisation that has the ability to leverage affective commitment of employees working within self-managing teams, and also improve working places through open dialogue and inquiry. Based on this, the following hypothesis has been formulated:

H2. The adoption of systems thinking approach in service operations design is positively related to improved social benefits to customers and employees.

\section{Systems thinking and economic performance}

A central tenet in the literature is that effective sustainable designs must be able to promote economic growth of firms while at the same time developing social dimension and decreasing harm to the environment; this is also known as "decoupling" (Karakosta and Charikleia, 2016; Prendeville and Bocken, 2017). Chou et al. (2012) posit that this is only possible through the adoption of systems thinking. However, only a few studies explore the effects of systems thinking on sustainability from an economic benefits dimension (for example: Kamala, 1999; Jaaron et al., 2014). An inquiry into previous studies reveals that systems thinking can mainly contribute to economic growth through 
reduced resources consumption. For example, Fiksel (2012), in his discussion of strategies for reducing resources consumption from a systems thinking perspective, explained that increasing resources efficiency in operations of a facility is closely linked with reduced costs. Similarly, Jaaron et al. (2014) identified that interconnectedness of service system parts, warranted by systems thinking approach, can provide clarity for the system as whole by analysing demand arriving into the system. This was found to significantly improve service demand predictability and, thus, better organisational preparedness for required resources will save organisational financial resources. Furthermore, Smith (2011) found that systems thinking allows for operational skills and personnel experience development. These benefits of systems thinking are relevant to the achievement of reduced operational errors and reduced resources wastage, thus, providing economic benefits for the business (Jaaron et al., 2014). According to Bicheno and Holweg (2016), resources depletion of a service organisation is caused by several types of wastes such as lack of preparedness that cause the inability to provide what a customer wants, duplication of processes, unclear communication, human errors, and delivery delays. These causes of resources depletion are also asserted by Seddon (2008) and Marshall (2010) as a result of flawed design of service operations. From a sustainable service design perspective, waste reduction requires a systems approach of treating service systems as a unit of analysis that allows for the optimal configuration of resources (Chowdhury and Quaddus, 2016; Jackson et al., 2008). This, in turn, deliver economic benefits, among other indirect benefits (such as employee satisfaction and customer retention) for the organisation (Prendeville and Bocken, 2017). On another hand, several researchers have linked systems thinking application with achieving financial benefits through customer satisfaction (Arnold, 2017; Jackson et al., 2008; Missimer et al., 2017; Mutingi and Mbohwa, 2014). In marketing literature, customer 
satisfaction has been endorsed as crucial for reducing organisational spending on customers' complaints and field service recovery. It has also highlighted the value of satisfied customers in purchasing more of the organisations services and products and attracting new customers (Blattberg et al., 2009; Terpstra and Verbeeten, 2014). According to Yeung and Ennew (2001), customer satisfaction can have a positive impact on organisational net profits through increased sales. Therefore, it can be discerned, then, that systems thinking can enhance economic prosperity of an organisation through customer satisfaction. These relationships are articulated more formally as:

H3. The adoption of systems thinking approach in service operations design is positively related to the economic performance of service organisations.

\section{TBL interrelationships: re-conceptualizing sustainability in services}

Adetunji et al. (2003), in their investigation of the model of sustainability development in both manufacturing and services sectors, indicated that the predominant use of the TBL of sustainability implies that all three dimensions are equally weighted. According to authors, this has caused failure in understanding the underlying concept of sustainability; that is environmental performance is preconditional to social and economic performance. In support of this view, Sridhar and Jones (2013) explained that both manufacturing and service organisations nowadays are using their environmental performance to impact the market and achieve social benefits, and ultimately, economic gains. Yet, the authors assert that due to lack of systems thinking approaches in the process of integrating imperatives of environmental protection with social benefits and organisational profitability, many service organisations around the globe are unable to combine the very different and often competing TBL of sustainability. At a more subtle level, Gimenez et al. (2012) pointed out that the adoption of environmental management 
programs in business operations is an antecedent of delivering social benefits for both internal employees and external customers. In service departments, the application of systems thinking principles help deliver a service with least process duplications, errors, and delays. Thus, helping employees deliver the service with minimal consumption of resources (Jaaron and Backhouse, 2011; Jaaron et al., 2014). This improves working conditions of employees with less work-related stress and better connectedness within organisational working teams and, on the other hand, provides customers with better quality of life with providing customers with what they exactly want, how, and when they would like to be served (Gimenez et al., 2012; Jackson et al., 2008). Therefore, the implementation of environmental management programs improves service organisations' social benefits for employees and customers. Accordingly, the following hypothesis is formulated:

H4. Environmental performance of service organisations is positively associated with creating social benefits to employees and customers.

On another hand, probably the most powerful criticism to neglecting primacy of environmental performance on the favor of economic performance comes from Seghezzo (2009). He illustrated that the Nations' (1987) definition of sustainability development has failed in maintaining main purpose of sustainability (i.e. protecting the environment) for several reasons. First, the Nations's (1987) report overestimates the dimension of economy by emphasizing that it is the only way to avoid social and environmental catastrophes. Second, the report ensures that the promotion of economic aspects (such as lower interest rates, technology advancement, and larger capital flows) is the way for achieving growth at all levels. Third, the report also sees that economic growth is central for solving problems of justice and equitable development. However, several researchers argue that service organisations that adopt environmental 
management programs and green policies in their operations management functions can achieve cost savings due to reduced resources consumption and improved efficiency (Angelia and Suryaningsih, 2015; Nakao et al., 2007; Wang, 2017). Recently, Hakkon et al. (2014) examined the role of corporate environmental responsibility in enhancing return on assets of major financial services in Korea. It was evident that pursuing an environment-centered industry policy in these service operations provided economic benefits. Similarly, Lucas and Wilson (2008) provided empirical evidence that the implementation of environmental management practices are positively associated with improved financial performance in the context of the service industry. Based on their results, authors argue that it pays for service organisations to use environmentally friendly practices that build cleaner service departments. This is also asserted by Jaaron et al. (2014) who found that designing service operations around the principles of systems thinking can provide a cleaner service department. This was found to be strongly linked with resource consumption reduction that has positively affected services' financial bottom line. Accordingly, the following hypothesis is presented:

H5. Environmental performance of service organisations is positively associated with economic performance.

To conceptualize the TBL interrelationships further, Wang and Berens (2015) found a positive impact of social performance of service organisations on their financial performance; mediated by improved reputation among customers and employees. Further, Rodriguez-Fernandez (2016) empirically investigated the bidirectional relationship between social performance and financial performance in Spanish listed services and manufacturing organisations. He found that better social performance policies transform into increased profits and increased profits transform into better social performance; thus, reflecting a concrete relationship. It is as posited by Missimer 
et al. (2017), a systems thinking approach to social aspect of sustainability, represented by customers, is the most significant asset to sustainability, as paying attention to the needs of customers interacting with an organisation can drive organisations' financial well-being. According to Boaventura et al. (2012), a service organisation that invests in creating a rewarding working experience of its employees will more easily achieve superior financial performance due to having a good service quality that attracts customers. As a result, neglecting the social aspect of sustainability, or at least not considering it as proactive to reputation and financial stability, presents a major impediment to service organisations facing the challenge of implementing sustainability in their daily work (von Geibler et al., 2006; Chaves et al., 2010; John et al., 2017). Based on this, the following hypothesis is formulated:

H6. Social benefits to employees and customers are positively associated with economic performance of service organisations.

Based on these research hypotheses a research model is presented in Figure 1.

[Figure 1 near here]

\section{Research Methodology}

In this research, a survey was carried out to investigate the six research hypotheses formulated. The survey was designed based on a literature review in organisational sustainable performance and systems thinking for service operations design research areas. In addition, the process of developing the survey benefited from several previous longitudinal case studies on the application of systems thinking in service organisations carried out by the authors of this paper in the period of 2008 up to 2017 . These previous longitudinal case studies aimed at exploring impact of implementing Seddon's systems thinking approach on organisational resource utilisation and operational cost reduction. To further enhance content validity of the survey, it was refined and validated with three 
academics with extensive background in sustainability and operations management issues from two UK-based universities. The three academics were requested to check consistency of the survey with available literature and viability of the concepts presented in practical terms; the feedback received was positive. Moreover, the survey instrument was shared with four systems thinking consultants, whom the authors worked with in their previous longitudinal case studies. These consultants responded to the survey questions based on their past experiences. To reduce any potential for bias, consultants were informed that there is no "right" or "wrong" answers, and that their inputs would be confidential and will only be used for academic purposes (Podsakoff et al., 2003). Consultants provided useful feedback on items arrangement and formulation; they indicated that some items would benefit from further details to identify the intended meaning. For example, the item "Improved team working" was reworded to become "Improved team working, learning and self-development". Also, the item "Reduction of customer complaints" was reworded to become "Reduction of costs associated with customer complaints". Thereafter, the final survey instrument contained four different sections with 29 items. First section included items that describe respondents' demographic and organisation information. Second section was composed of items describing service operations practices. Third section provided items that assess improvements in practices related to TBL of sustainable performance after the systems thinking redesign. Finally, fourth part aimed at gathering information on top management support (TMS) to sustainable performance issues.

\section{Sampling and Data collection}

However, to pinpoint, and then only target service organisations implementing Seddon's (2003) systems thinking approach into their service operations, a leading consulting firm in England, specialising in providing consultancy services around the systems 
thinking implementation in service organisations was contacted. An earlier research work of authors with the help of this consulting firm, over the period of 2008 up to early 2017, ensured easy access to available list of their clients, and ensured easy access to service organisations' annual reports. To mitigate the concerns about omitted variables bias, authors explored 197 annual reports, which belong to participating service organisations in the survey, in which management provides a discussion and analysis of the previous years' operations and how the organisation performed. Authors examined sustainable performance reflected in the sentences that contain causative words (e.g. "because" and "as a result of"). It was found that positive sustainable performance in the causative sentences is associated with operational aspects of the systems thinking design used. This evidence shows that unobserved organisation-year specific variables (such as corporate social responsibility or competitive advantage) are less likely to explain the association between systems thinking implementation and sustainable performance.

The targeted organisations were a mixture of logistics of housing repair and maintenance, insurance, financial, and IT support services that have all implemented systems thinking approach into their service operations design. According to Jaaron and Backhouse (2016), although service organisations, implementing systems thinking approach, can belong to different industrial sectors, they tend to share exact service principles that yield various operational and behavioural similarities. Data were collected over a period of six months in spring and summer of 2017. A web-based survey that has been sent to 250 service organisations through e-mail (i.e. available list of service organisations fully implementing the systems thinking approach), after organisations were first contacted by e-mail to explain the research project. The survey was completed by general directors, operation managers, systems thinking team leader, 
or the person responsible for the sustainability development in the organisation. Respondents were requested to rate each item in the survey on a Likert scale (1-not at all, 2-slightly, 3-moderately, 4-very, 5-extremely). The web-based survey provided easy and relatively quick gathering of data (Creswell, 2012). The sample of service organisations participated in the survey was 183; responding to all items in the survey and representing a response rate of $73.2 \%$. Figure 2 shows the distribution of participating organisations according to industry type, and Table 1 provides details of participating service organisations in terms of size, type or respondent, and number of years since the systems thinking adoption in service operations.

[Figure 2 near here]

[Table 1 near here]

\section{Data analysis and results}

To analyse the data, the Structural Equation Modelling (SEM) technique was used. SEM is a multivariate statistical analysis method that is used to analyse the structural relationships between measured variables and latent constructs (Kline, 2015). It was chosen in this research for two main reasons. First, this technique allows for studying both latent and directly measured variables. The use of latent variables enhances the accuracy of the measurement of the mediated effect. This will, in turn, yield a higher statistical power to identify mediating effect than traditional regression analysis. Second, the strength of this method emanates from its flexibility to test various dependency relationships simultaneously, while also measuring the intensity of these relationships (Fabrigar et al., 2010; Hair et al., 2014). Sideridis et al. (2014) explain that to have good results in using SEM method, the sample size must be linked with number of measured indicators and latent variables in the structural model. According to authors, "designs having more than 20 measured indicators and between 4 and 10 latent 
variables, all required fewer than 100 participants". In this research, the structural model (shown in Figure 1) is based on 26 measured indicators and four latent variables. As it was mentioned earlier, the sample of service organisations participated in the survey was 183 , which is higher than the minimum recommended criterion provided by Sideridis et al. (2014). Statistical analysis of the data was conducted with the help of the SPSS software (Statistical Package for Social Sciences) Version 23, as well as to the viability of SEM methods was performed using IBM SPSS Amos 23. In accordance with the aim of this research, the practices of the systems thinking approach for service operations are used as the exogenous (independent) latent variable, whereas the TBL of sustainable performance (i.e. environmental, social, and economic dimensions) were used as the endogenous (dependant) latent variables. However, we control for the effect of size of organisation (in terms of number of employees) and TMS for sustainability initiatives on the TBL of sustainable performance.

\section{Reliability and validity}

To ensure validity and reliability of the data, five different techniques were used for this purpose. First, content validity, as mentioned earlier, was addressed in the survey development process through pre-testing with academics, for consistency of survey items with available literature, and through sharing with systems thinking practitioners. Second, the Harman's single factor test was used to test the data for common bias or variance. In this test, all survey variables were loaded onto a virtually added single factor and constrained so that there is no rotation. It was found that the newly introduced single factor only explains $43.29 \%$ of the variance. According to Podsakoff et al. (2003) a score below 50\% is normally accepted as they represent absence of common method bias. Third, to validate factors structure in the model, convergent validity was tested with the help of Confirmatory Factor Analysis (CFA) technique. The 
model fit was assessed with the help of three different indices widely used in CFA; the Tucker-Lewis Index (TLI), Comparative Fit Index (CFI), and the Root-Mean-Square Error of Approximation (RMSEA). The results of the CFA technique indicated that TLI and CFI values are 0.952 and 0.957 , respectively, and that the RMSEA value is 0.061 . According to $\mathrm{Hu}$ and Bentler (1999), cut-off values close to 0.06 for RMSEA, and a cut-off values above 0.90 for TLI and CFI indicate a good fit between the hypothesised model and the observed data. These cut-off values for a good model fit have also been supported by Kline (2015). Furthermore, all specified factor loadings were highly significant in the CFA as they all exceeded the value of 0.5 . In addition, t-values have been found to be greater than 2.0. These values indicate good convergent validity among the measures of each construct (Longoni and Cagliano, 2016; Vickery et al., 2003). Table 2 provides detailed CFA results.

[Table 2 near here]

Fourth, discriminant validity was demonstrated using the Average Variance Extracted (AVE) method as introduced by Fornell and Larcker (1981). Fornell and Larcker (1981) suggested that discriminant validity is established if the AVE of each construct in a model is higher than 0.50 ; to guarantee that more than 50 percent of the construct's variance is due to its indicators and not due to other constructs in the same model (Henseler et al., 2014). In this research, it was found that all AVE values of different constructs in the model are higher than the minimum required value (see Table 3). Finally, to test for construct reliability, Composite Reliability (CR) values have been calculated. It is widely supported that $\mathrm{CR}$ values of 0.7 or higher indicate high reliability (Hair et al., 2014). The CR values shown in Table 3 are all above the threshold of 0.7 , thus demonstrating high construct reliability.

[Table 3 near here] 


\section{Hypotheses testing}

In this section, the results for testing the six hypotheses presented in structural model in Figure 1 are described. The results of the analysis are shown in Table 4 and summarised in Figure 3. The results show that hypotheses H1, H2, H5, and H6 are all supported. However, hypotheses $\mathrm{H} 3$ and $\mathrm{H} 4$ are not supported. The structural model fit indices show an adequate model fit, with $\mathrm{CFI}=0.923$ and $\mathrm{TLI}=0.913$, which are well above the minimum threshold of 0.9 required in SEM (Kline, 2015; Ponis et al., 2017). In addition, the $\mathrm{RMSEA}=0.065$, which is very close to 0.060 as recommended by $\mathrm{Hu}$ and Bentler (1999). Furthermore, the path coefficients for hypotheses H1, H2, H5, and H6 are significant at $(\mathrm{p}<0.05)$ level. The results also demonstrate that top management support to sustainability initiatives has a positive impact on the environmental and the social performance at the 0.001 level, but it has no impact on economic performance of service organisations. Finally, size of organisation was found to have no impact on any of the TBL of sustainable performance.

[Table 4 near here]

[Figure 3 near here]

\section{Discussion}

The overall hypotheses testing results achieved through the SEM technique have proven that there is a statistically positive and significant relationship between applying systems thinking principles in service operations and the environmental performance and social benefits of employees and customers. However, contrary to what was predicted, systems thinking approach was found not to have a direct impact on the economic performance of service organisations. Focusing on the positive impact of systems thinking on environmental performance (i.e. H1), the following explanations are suggested here. First, and as it was scrutinized in literature review, the value of 
systems thinking to environmental performance is explained through the ability of building an operational system that can respond to feedback from different customers on its environmental performance (Jaaron and Backhouse, 2016; Lezak and Thibodeau, 2016). This adaptive capacity of systems thinking design allows transformation of internal operations to reduce resources depletion and, thus, improve environmental protection. In specific, continuous adaptation to customer demand patterns, made possible by interconnectedness of subsystems of a service, facilitate information flows and decision making processes required for the development of environmental problems solving (Dougherty and Dunne 2011). In line with these virtues, systems thinking application has the potential of not only absorbing various customer demands, but also increasing material efficiency in operations; delivering a service with least repeated contacts and paperwork, thus reducing energy utilization. Second, the results suggest that working principles of systems thinking such as "matching and predicting customer demand", and "less failure demands" (see Table 2) are significantly important for waste management. Overall, readiness and preparedness for customer demands, through predicting customer demand, lead to the development of strategies for increasing resources efficiencies through matching customer demand with least resources consumption (Arnold, 2017; Trevisan et al., 2012). This is because readiness and preparedness lead to identification of most required resources beforehand, thus, eliminating those resources that were brought into the service operations because of the mistaken belief that it would be required at some later stage of serving customers. Third, sticking to the operational principle of only collecting correct information from customers may have also contributed to the positive effect of systems thinking design on environmental performance. If only correct information is collected by employees through enhancing employee-customer communication, then chances of errors are 
minimized. This may dramatically reduce the repetition of customer contacts/visits, which will allow for resource savings. As for positive impact of systems thinking on providing social benefits to customers and employees (i.e. H2), the findings suggest that systems thinking provide a rewarding experience for both. As it was mentioned in literature, systems thinking application has the capability of improving human wellbeing through changing behaviour at work (Smith, 2011). Behavioural changes include relocating employees to work within teams, thus, creating a working place where employees share values, interests, information, and eventually, they get the chance to improve their competencies through learning from each other. Customers also become the focus in this context, thus, increasing their satisfaction with the service organisation (Jaaron and Backhouse, 2011). In fact, sustainable performance depends on shared values among employees in a service system to create changes in the consumption pattern of organisational resources. This can only be warranted by the creation of new forms of interaction between individuals, inside and outside the boundaries of the organisation (i.e. between employees and customers), which may result in improved sustainable practices. The findings also demonstrate that systems thinking plays an important role in changing the employee-managers' relationship. Managers, in systems thinking workplace, change their role from monitors to supporters where they trust employees to make decisions necessary for the work (Wong et al., 2011); this inevitably enhances employees' feeling of ownership of the working place and expose them as experts in their field. This new mindset of viewing employees saves available resources and generates a customer-focused service (Manz et al., 2015). Therefore, it is suggested here that systems thinking application to service operations eliminates mechanisms of systematic degradation of the social systems at the employees and customer levels and maintains conditions that are necessary for flourishing of employees' well-being. 
At a subtle level, it is interesting to notice that the missing link between systems thinking application and economic performance (i.e. H3) can also be explained through explaining the positive relationship between environmental performance and economic performance in the structural model (i.e. H5). As depicted in results (see Table 2), the top most offering of systems thinking application to service operations is the reductions of failure demands with a total mean of 4.33. This minimization of failures is associated with reduction in resources waste. According to Seddon (2008), failure demands can produce many types of wastes that can affect operational costs, such as duplication due to repeated customer contacts, significant delays, more back office paperwork, and more time wastage; thus, causing reduced productivity and less profits. It can also be discerned from results that the second two most offerings of systems thinking are employees' satisfaction and customer satisfaction with a total mean of 4.22 and 4.18 , respectively. As mentioned earlier, employees in a systems thinking design enjoy operational skills and personnel experience development (Smith, 2011). This would imply that employees, in this context, are well-prepared to provide a high-quality service, thus, providing economic benefits through more satisfied customers. Following this logic, one may expect that systems thinking can only contribute to economic growth of service organisations through enhanced resources efficiencies at the environmental dimension of sustainable performance. In other words, environmental performance mediates the relationship between systems thinking application and economic performance in terms of delivering economic benefits. These results are in congruence with Cordero et al. (2005) who concluded that the adoption of environmentally adapted techniques is associated with economic growth through more efficient operations. These results are also matching Nevado-Peña et al.'s (2015) 
findings of the importance of the precedence of environmental dimension of sustainability in improving economy.

Moreover, the positive relationship between environmental performance and economic performance (i.e. H5) and between social performance and economic performance (i.e. H6) in the structural model, supports the notion that the TBL of sustainable performance should not be viewed as equally weighted, as already proposed by several researchers (e.g. Adetunji et al. (2003); Seghezzo (2009); and Martínez León and Calvo-Amodio (2017)). Although the lack of significant relationships between environmental performance and social performance (i.e. H4) suggests neutral relationships between these two constructs, both environmental and social performances seem to be preconditional for the economic performance. This matches what Despotovic et al. (2016) have found on the positive impact of social and environmental performance on the economic performance of European countries. In fact, the relationship between social and economic performance (i.e. H6) is justifiable as providing a work environment that can improve employees' well-being, through motivation and retention, can increase customer loyalty and sales, and eventually, increase economic growth of the organisation (Blattberg et al., 2009; Terpstra and Verbeeten, 2014). However, the missing link between the environmental performance and the social performance (i.e. H4) can be explained by the fact that the growing number of organisations adopting environmentally friendly practices, in developed countries, is no longer a differentiating factor in increasing customer satisfaction (Longoni and Cagliano, 2016). In addition, the type of environmental practices studied in this research are related to waste reduction, energy reduction, and reduction of organisational resources consumption that rely on continuous creation of new 
operational designs. Due to this, Some employees may have experienced stress due to an evolving workplace operations (Becker, 2008).

The other notable finding in this research is that TMS is significantly linked with both environmental and social performances, but not with the economic performance. It is suggested here that this is because top management aims at building value-driven service organisation (Painter-Morland, 2008), that can indirectly improve financial winnings (Boiral et al., 2014). Changing the top management role from command-andcontrol to supporters, through systems thinking, promotes ethical behaviour and provides a decentralised decision-making authority. Adopting ethical behaviour suggests that top management is also committed to deploying environmental protection measures, and thus reinforcing organisational intention to implement consumption systems' changes, that may, ultimately, enhance economic performance. In addition to this, size of organisation did not impact any of the TBL of sustainable performance. This would suggest that benefits of systems thinking approach to sustainable performance of services could be achieved by all service organisations regardless of their size.

\section{Conclusions}

The main aim of this research study was to contribute to literature on the influence of systems thinking over organisational sustainable performance by empirically investigating the impact of applying systems thinking approach to service operations design on the TBL of sustainable performance. The study demonstrates an interesting dynamic of the systems thinking application to service operations that can provide an understanding of how sustainable performance can be fostered in service industries. 


\section{Theoretical implications}

Previous studies investigating the impact of systems thinking on sustainable performance have been scarce and only focused at the conceptual level (Fiksel, 2012; Smith, 2011; Starik and Kanashiro, 2013; Waller et al., 2015; Williams et al., 2017; Zhang et al., 2012). This research study has several contributions for practitioners and researchers. First, most research in the field of service operations design investigates sustainable development based on the product-based domain; where the focus is on economic value as it is relatively more tangible than in service setting; see for example the work of Chou et al. (2012), Trevisan et al. (2012), and Fiksel (2012). This paper sets to empirically investigate the impact of systems thinking design approach on the TBL of sustainable performance in the context of service departments. Second, while previous research has showed limited capability in designing sustainable services (Arnold, 2017; Manz et al., 2015), that can remain financially stable while simultaneously contributing to social benefits and clean production of services, this current research provides an evidence that systems thinking approach, in a service setting, ensures the service system design is directly linked with enhanced environmental and social benefits while indirectly contributing to the economic benefits. Third, this paper is among the first generation of studies that acknowledges that the environmental and social dimensions of the TBL of sustainable performance in services are preconditional for the economic performance. In this regard, the interrelationship among the TBL of sustainable performance is proposed and tested separately, thus, providing a nuanced view to re-conceptualizing sustainable performance. 


\section{Practical implications}

Based on results, the first practical implication for service managers is that applying systems thinking approach in service operations design provides leverage for developing social benefits for both employees and customers. In specific, systems thinking directly creates a social system where both employees and customers build mutual trust, common meaning, and shared values that can be used to improve consumption pattern of organisational resources. This can be particularly useful for service managers who are faced with the decision to choose from various options for managing their employee-customer relationships, from a sustainable performance point of view. Second, service managers can use systems thinking as a strategy to develop an environmentally oriented business model that can reduce consumption of scare resources. This is very topical nowadays given the fact that improving organisational environmental performance is a main differentiator for retaining customers, as well as employees (Longoni and Cagliano, 2016). Third, the results of this research help service organisations acknowledge the role of environmental protection practices and social well-being of customers and employees in creating economic benefits, thus mitigating the barriers for the acceptance of systems thinking approach for service design. Fourth, adopting systems thinking principles helps service organisations to build an ecoadvantage culture of going beyond mere waste reduction to embrace environmental values in all aspect of their employees' activities. However, to reap the benefits of such a culture, top management in service organisations is encouraged to strongly support sustainability improvement initiatives; as they are leverage points for competitive advantage (Gürlek \& Tuna, 2018). 


\section{Limitations and future research work}

This study has some limitations which may pave the way for further research in the future. First, although different industries were included in this study (i.e. logistics of housing repair and maintenance, financial, insurance, and IT support services), they all came from the same country. This may limit generalisability of the results. A replication of the study in other countries and contexts will be ideal. Second, this research was conducted using relevant attributes of systems thinking mainly from the literature; therefore, the set of principles and aspects included might not be fully comprehensive. Future research might adopt action research methodologies that allow for the identification of other principles of systems thinking that might have been missed in this study. Third, the structural model adopted in this research used only two control variables (i.e. size of organisation and TMS) to control for the impacts on TBL of sustainable performance. It would be valuable for future research to explore impacts of other control variables such as number of years of using systems thinking design in service operations and position of respondents. Finally, the unpredicted missing link between the environmental and social dimensions of sustainability in the structural model used (i.e. H4) in this study might benefit from the inclusion of possible moderators. It was explained in this paper that one reason behind this missing link is the possible stress experienced by some employees caused by evolving workplace operations. However, future research might look at moderating effects of change management and other human resources management practices that may reduce this negative effect.

\section{References}

Ackoff, R. L. (1981). Creating the corporate future : plan or be planned for. Wiley. 
Adetunji, I., Price, A., Fleming, P., \& Kemp, P. (2003). The Application of Systems Thinking To the Concept of Sustainability. 19th Annual ARCOM Conference, 1(September), 161-170.

Angelia, D., \& Suryaningsih, R. (2015). The Effect of Environmental Performance And Corporate Social Responsibility Disclosure Towards Financial Performance (Case Study to Manufacture, Infrastructure, And Service Companies That Listed At Indonesia Stock Exchange). Procedia - Social and Behavioral Sciences, 211, 348355. https://doi.org/10.1016/J.SBSPRO.2015.11.045

Arnold, M. (2017). Fostering sustainability by linking co-creation and relationship management concepts. Journal of Cleaner Production, 140, 179-188. https://doi.org/10.1016/j.jclepro.2015.03.059

Arnold, R.D., \& Wade, J.P. (2015). A Definition of Systems Thinking: A Systems Approach. Procedia Computer Science, 44, 669-678.

Ashton, W. S. (2009). The Structure, Function, and Evolution of a Regional Industrial Ecosystem. Journal of Industrial Ecology, 13(2), 228-246. https://doi.org/10.1111/j.1530-9290.2009.00111.x

Bamgbade, J. A., Kamaruddeen, A. M., \& Nawi, M. N. M. (2017). Malaysian construction firms' social sustainability via organizational innovativeness and government support: The mediating role of market culture. Journal of Cleaner Production, 154, 114-124. https://doi.org/10.1016/j.jclepro.2017.03.187

Becker, K. (2008). Unlearning as a driver of sustainable change and innovation: three Australian case studies. International Journal of Technology Management, 42(1/2), 89. https://doi.org/10.1504/IJTM.2008.018062

Bell, S., \& Morse, S. (2005). Delivering sustainability therapy in sustainable 
development projects. Journal of Environmental Management, 75(1), 37-51. https://doi.org/10.1016/j.jenvman.2004.11.006

Bicheno, J., \& Holweg, M. (2016). The lean toolbox a handbook for lean transformation. Picsie Books. Retrieved from http://eureka.sbs.ox.ac.uk/6225/

Blattberg, R. C., Malthouse, E. C., \& Neslin, S. A. (2009). Customer Lifetime Value: Empirical Generalizations and Some Conceptual Questions. Journal of Interactive Marketing, 23(2), 157-168. https://doi.org/10.1016/j.intmar.2009.02.005

Blok, V., Wesselink, R., Studynka, O., \& Kemp, R. (2015). Encouraging sustainability in the workplace: a survey on the pro-environmental behaviour of university employees. Journal of Cleaner Production, 106, 55-67. https://doi.org/10.1016/j.jclepro.2014.07.063

Boaventura, J. M. G., Silva, R. S. da, \& Bandeira-de-Mello, R. (2012). Performance Financeira Corporativa e Performance Social Corporativa: desenvolvimento metodolÃ|textthreesuperiorgico e contribuiÃßÃ \poundso teÃ|textthreesuperiorrica dos estudos empÃl-ricos. Revista Contabilidade \& FinanÃ|Sas, 23, 232-245. Retrieved from http://www.scielo.br/scielo.php?script=sci_arttext\&pid=S1519$70772012000300008 \& n r m=i s o$

Boiral, O., Baron, C., \& Gunnlaugson, O. (2014). Environmental Leadership and Consciousness Development: A Case Study Among Canadian SMEs. Journal of Business Ethics, 123(3), 363-383. https://doi.org/10.1007/s10551-013-1845-5

Bosch, O. J. H., King, C. A., Herbohn, J. L., Russell, I. W., \& Smith, C. S. (2007). Getting the big picture in natural resource management-systems thinking as ?method? for scientists, policy makers and other stakeholders. Systems Research and 
Behavioral Science, 24(2), 217-232. https://doi.org/10.1002/sres.818

Botla, L. (2009). Systems Thinking: The Gandhian Way. Journal of Human Values, 15(1), 77-90. https://doi.org/10.1177/097168580901500106

Cabrera, D., Colosi, L., \& Lobdell, C. (2008). Systems thinking. Evaluation and Program Planning, 31(3), 299-310. https://doi.org/10.1016/j.evalprogplan.2007.12.001

Chaves, R., Mozas, A., Puentes, R., \& Bernal, E. (2011). E-corporate social responsibility in socially responsible firms: the case of Spanish firms. The Service Industries Journal, 31(12), 2033-2050.

Chou, C. J., Chen, C. W., \& Conley, C. (2012). A systematic approach to generate service model for sustainability. Journal of Cleaner Production, 29-30, 173-187. https://doi.org/10.1016/j.jclepro.2012.01.037

Chowdhury, M. M. H., \& Quaddus, M. A. (2016). A multi-phased QFD based optimization approach to sustainable service design. International Journal of Production Economics, 171, 165-178. https://doi.org/10.1016/j.ijpe.2015.09.023

Cocca, S., \& Ganz, W. (2015). Requirements for developing green services. The Service Industries Journal, 35(4), 179-196.

Cordero, R. R., Roth, P., \& Da Silva, L. (2005). Economic growth or environmental protection? Environmental Science \& Policy, 8(4), 392-398. https://doi.org/10.1016/j.envsci.2005.04.005

Creswell, J. W. (2012). Educational research: planning, conducting, and evaluating quantitative and qualitative research. Pearson.

Davis, A. C., \& Stroink, M. L. (2016). The Relationship between Systems Thinking and the New Ecological Paradigm. Systems Research and Behavioral Science, 33(4), 575-586. https://doi.org/10.1002/sres.2371 
de Freitas, J. G., Costa, H. G., \& Ferraz, F. T. (2017). Impacts of Lean Six Sigma over organizational sustainability: A survey study. Journal of Cleaner Production, 156, 262-275. https://doi.org/10.1016/j.jclepro.2017.04.054

Despotovic, D., Cvetanovic, S., Nedic, V., \& Despotovic, M. (2016). Economic, social and environmental dimension of sustainable competitiveness of European countries. Journal of Environmental Planning and Management, 59(9), 1656-1678. https://doi.org/10.1080/09640568.2015.1085370

Dougherty, D., \& Dunne, D. D. (2011). Organizing Ecologies of Complex Innovation. Organization Science, 22(5), 1214-1223. https://doi.org/10.1287/orsc.1100.0605 Dunnion, J., \& O'Donovan, B. (2014). Systems Thinking and Higher Education: The Vanguard Method. Systemic Practice and Action Research, 27(1), 23-37. https://doi.org/10.1007/s11213-012-9258-4

Etzion, D. (2007). Research on Organizations and the Natural Environment, 1992Present: A Review. Journal of Management, 33(4), 637-664. https://doi.org/10.1177/0149206307302553

Evans, S., Partidário, P. J., \& Lambert, J. (2007). Industrialization as a key element of sustainable product-service solutions. International Journal of Production Research, 45(18-19), 4225-4246. https://doi.org/10.1080/00207540701449999

Fabrigar, L. R., Porter, R. D., \& Norris, M. E. (2010). Some things you should know about structural equation modeling but never thought to ask. Journal of Consumer Psychology, 20(2), 221-225. https://doi.org/10.1016/j.jcps.2010.03.003

Fiksel, J. (2012). A systems view of sustainability: The triple value model. Environmental Development, $\quad 2, \quad 138-141$. https://doi.org/10.1016/j.envdev.2012.03.015 
Folke, C., Carpenter, S. R., Walker, B., Scheffer, M., Chapin, T., \& Rockström, J. (2010). Resilience thinking: Integrating resilience, adaptability and transformability. Ecology and Society, 15(4). https://doi.org/10.1038/nnano.2011.191

Fornell, C., \& Larcker, D. F. (1981). Evaluating Structural Equation Models with Unobservable Variables and Measurement Error. Journal of Marketing Research, 18(1), 39-50. https://doi.org/10.2307/3151312

Gadenne, D., Mia, L., Sands, J., Winata, L., \& Hooi, G. (2012). The Influence of Sustainability Performance Management Practices on Organisational Sustainability Performance. Journal of Accounting \& Organizational Change, 8(2), 210-235.

Gibson, J., \& O'Donovan, B. (2014). The Vanguard Method as Applied to the Design and Management of English and Welsh Children's Services Departments. Systemic Practice and Action Research, 27(1), 39-55. https://doi.org/10.1007/s11213-0139281-0

Gimenez, C., Sierra, V., \& Rodon, J. (2012). Sustainable operations: Their impact on the triple bottom line. International Journal of Production Economics, 140(1), 149159. https://doi.org/https://doi.org/10.1016/j.ijpe.2012.01.035

Gray, R. (2010). Is accounting for sustainability actually accounting for sustainability?and how would we know? An exploration of narratives of organisations and the planet. Accounting, Organizations and Society, 35(1), 4762. https://doi.org/10.1016/j.aos.2009.04.006

Gregory, A. J. (2007). Target Setting, Lean Systems and Viable Systems: A Systems Perspective on Control and Performance Measurement. The Journal of the Operational Research Society, 58(11), 1503-1517. Retrieved from 
http://www.jstor.org/stable/4622844

Gürlek, M., \& Tuna, M. (2018). Reinforcing competitive advantage through green organizational culture and green innovation. The Service Industries Journal, 38(7-8), 467-491.

Hair, J. F., Black, W. C., Babin, B. J., \& Anderson, R. E. (2014). Multivariate Data Analysis. New York: Pearson Education Limited.

Hakkon, H. J., Park, K. K., Jo, H., Kim, H., \& Park, K. (2014). Corporate Environmental Responsibility and Firm Performance in the Financial Services Sector. Seoul, South Korea. Retrieved from http://ssrn.com/abstract=2470872

Henseler, J., Ringle, C. M., \& Sarstedt, M. (2014). A new criterion for assessing discriminant validity in variance-based structural equation modeling. https://doi.org/10.1007/s11747-014-0403-8

Hu, L., \& Bentler, P. M. (1999). Cutoff criteria for fit indexes in covariance structure analysis: Conventional criteria versus new alternatives. Structural Equation Modeling: A $\quad$ Aultidisciplinary Journal, 6(1), 1-55. https://doi.org/10.1080/10705519909540118

Jaaron, A. A. M., \& Backhouse, C. J. (2011). Systems thinking for call centre service design: affective commitment implications in manufacturing enterprises. The $\begin{array}{lll}\text { Service } \quad \text { Industries } \quad \text { J1(4), } & \text { 613-628. }\end{array}$ https://doi.org/10.1080/02642069.2010.504301

Jaaron, A. A. M., \& Backhouse, C. J. (2016). Operationalising “Double-Loop” Learning in Service Organisations: A Systems Approach for Creating Knowledge. Systemic Practice and Action Research, 1-21. https://doi.org/10.1007/s11213-016-9397-0 Jaaron, A. A. M., \& Backhouse, C. J. (2017). Operationalisation of service innovation: a 
systems thinking approach. The Service Industries Journal, 0(0), 1-23. https://doi.org/10.1080/02642069.2017.1411480

Jaaron, A., Backhouse, C. J., \& Morton, S. C. (2014). Enhancing resource utilisation in service industries: the application of the Vanguard Method of systems thinking. European Journal of Industrial Engineering, 8(6), 861-883. https://doi.org/10.1504/EJIE.2014.066938

Jackson, M. C., Johnston, N., \& Seddon, J. (2008). Evaluating Systems Thinking in Housing. Source: The Journal of the Operational Research Society, 59(59), 186197. https://doi.org/10.1057/palgrave.jors.2602521

Jo, H., Kim, H., \& Park, K. (2015). Corporate Environmental Responsibility and Firm Performance in the Financial Services Sector, Journal of Business Ethics, 131(2), 257-284. https://doi.org/10.1007/s10551-014-2276-7

John, A., Qadeer, F., Shahzadi, G., \& Jia, F. (2017). Corporate social responsibility and employee's desire: a social influence perspective. The Service Industries Journal, 37(13-14), 819-832.

Junnila, S. (2006a). Alternative Scenarios for Managing the Environmental Performance of a Service Sector Company. Journal of Industrial Ecology, 10(4), 113-131. https://doi.org/10.1162/jiec.2006.10.4.113

Junnila, S. (2006b). Empirical Comparison of Process and Economic Input-Output Life Cycle Assessment in Service Industries. Environmental Science \& Technology, 40(22), 7070-7076. https://doi.org/10.1021/es0611902

Kamala, D. (1999). A Systems Thinking Model for Economic Management the Case of Tanzania. In A. M. Castell, A. J. Gregory, G. A. Hindle, M. E. James, \& G. Ragsdell (Eds.), Synergy Matters: Working with Systems in the 21st Century (pp. 451-456). 
Boston, MA: Springer US. https://doi.org/10.1007/0-306-47467-0_76

Karakosta, C., \& Charikleia. (2016). A Holistic Approach for Addressing the Issue of Effective Technology Transfer in the Frame of Climate Change. Energies, 9(7), 503. https://doi.org/10.3390/en9070503

Kline, R. B. (2015). Principles and practice of structural equation modeling (Fourth). Guilford Press.

Lezak, S. B., \& Thibodeau, P. H. (2016). Systems thinking and environmental concern. Journal of Environmental Psychology, 46, 143-153. https://doi.org/10.1016/j.jenvp.2016.04.005

Longoni, A., \& Cagliano, R. (2016). Human resource and customer benefits through sustainable operations. International Journal of Operations \& Production Management, 36(12), 1719-1740. https://doi.org/10.1108/IJOPM-11-2014-0564

Lucas, M. T., \& Wilson, M. A. (2008). Tracking the relationship between environmental management and financial performance in the service industry. Service Business, 2(3), 203-218. https://doi.org/10.1007/s11628-008-0035-5

Manring, S. L. (2014). The role of universities in developing interdisciplinary action research collaborations to understand and manage resilient social-ecological systems. Journal of Cleaner Production, 64, 125-135. https://doi.org/10.1016/j.jclepro.2013.07.010

Manz, C. C., Skaggs, B. C., Pearce, C. L., \& Wassenaar, C. L. (2015). Serving one another: Are shared and self-leadership the keys to service sustainability? Journal of Organizational Behavior, 36(4), 607-612. https://doi.org/10.1002/job.1991

Marcus, J., Kurucz, E. C., \& Colbert, B. A. (2010). Conceptions of the Business-SocietyNature Interface: Implications for Management Scholarship. Business \& Society, 
49(3), 402-438. https://doi.org/10.1177/0007650310368827

Marques, R. C., da Cruz, N. F., \& Pires, J. (2015). Measuring the Sustainability of Urban Water Services. Environmental Science \& Policy, 54(2015), 142-151.

Marshall, J. (2010). Organisational change: evaluating systems thinking in the UK housing sector- A work in progress'. In J. S. and B. O. K. Zokaei (Ed.), Systems Thinking: From Heresy to Practice, Public and Private Sector Studies (p. 108-131.). Basingstoke: Palgrave Macmillan.

Martínez León, H. C., \& Calvo-Amodio, J. (2017). Towards lean for sustainability: Understanding the interrelationships between lean and sustainability from a systems thinking perspective. Journal of Cleaner Production, 142, 4384-4402. https://doi.org/10.1016/j.jclepro.2016.11.132

Missimer, M., Robèrt, K. H., \& Broman, G. (2017). A strategic approach to social sustainability - Part 1: exploring the social system. Journal of Cleaner Production, 140, 32-41. https://doi.org/10.1016/j.jclepro.2016.03.170

Mog, J. M. (2004). Struggling with Sustainability-A Comparative Framework for Evaluating Sustainable Development Programs. World Development, 32(12), 2139-2160. https://doi.org/10.1016/j.worlddev.2004.07.002

Morgan, P. (2005). THE IDEA AND PRACTICE OF SYSTEMS THINKING AND THEIR RELEVANCE FOR CAPACITY DEVELOPMENT. Maastricht. Retrieved from http://ecdpm.org/wp-content/uploads/2005-Idea-Practice-Systems-ThinkingRelevance-Capacity-Development.pdf

Mutingi, M., \& Mbohwa, C. (2014). Understanding sustainability in healthcare systems: A systems thinking perspective. In Industrial Engineering and Engineering Management (IEEM), 2014 IEEE International Conference on (pp. 597-601). 
Bandar Sunway, Malaysia: IEEE. https://doi.org/10.1109/IEEM.2014.7058708

Nakao, Y., Amano, A., Matsumura, K., Genba, K., \& Nakano, M. (2007). Relationship between environmental performance and financial performance: an empirical analysis of japanese corporations. Business Strategy and the Environment, 16(2), 106-118. https://doi.org/10.1002/bse.476

Nations, U. (1987). Report of the World Commission on Environment and Development: Our Common Future. Retrieved from http://www.un-documents.net/wcedocf.htm

Nevado-Peña, D., López-Ruiz, V.-R., \& Alfaro-Navarro, J.-L. (2015). The Effects of Environmental and Social Dimensions of Sustainability in Response to the Economic Crisis of European Cities. Sustainability, 7(7), 8255-8269. https://doi.org/10.3390/su7078255

Nguyen, N. C., \& Bosch, O. J. H. (2013). A Systems Thinking Approach to identify Leverage Points for Sustainability: A Case Study in the Cat Ba Biosphere Reserve, Vietnam. Systems Research and Behavioral Science, 30(2), 104-115. https://doi.org/10.1002/sres.2145

Painter-Morland, M. (2008). Systemic Leadership and the Emergence of Ethical Responsiveness. Journal of Business Ethics, 82(2), 509-524. https://doi.org/10.1007/s10551-008-9900-3

Pham, D. T., \& Jaaron, A. A. M. (2017). Design for Mass Customisation in Higher Education: a Systems-Thinking Approach. Systemic Practice and Action Research. https://doi.org/10.1007/s11213-017-9426-7

Podsakoff, P. M., Mackenzie, S. B., Lee, J.-Y., \& Podsakoff, N. P. (2003). Common Method Biases in Behavioral Research: A Critical Review of the Literature and 
Recommended Remedies. Journal of Applied Psychology, 88(5), 879-903. https://doi.org/10.1037/0021-9010.88.5.879

Ponis, S. T., Papanikolaou, P.-A., Katimertzoglou, P., Ntalla, A. C., \& Xenos, K. I. (2017). Household food waste in Greece: A questionnaire survey. Journal of Cleaner Production, 149, 1268-1277. https://doi.org/10.1016/j.jclepro.2017.02.165

Prendeville, S., \& Bocken, N. (2017). Sustainable Business Models through Service Design. Procedia Manufacturing, 8(October 2016), 292-299. https://doi.org/10.1016/j.promfg.2017.02.037

Rodriguez-Fernandez, M. (2016). Social responsibility and financial performance: The role of good corporate governance. BRQ Business Research Quarterly, 19(2), 137151. https://doi.org/https://doi.org/10.1016/j.brq.2015.08.001

Roos, G., \& Agarwal, R. (2015). Services Innovation in a Circular Economy. In R. Agarwal, W. Selen, G. Roos, \& R. Green (Eds.), The Handbook of Service Innovation (pp. 501-520). London: Springer London. https://doi.org/10.1007/978-1-44716590-3_23

Rosenblum, J., Horvath, A., \& Hendrickson, C. (2000). Environmental Implications of Service Industries. Environmental Science \& Technology, 34(22), 4669-4676. https://doi.org/10.1021/es9914083

Russo, M. V., \& Minto, A. (2011). Competitive Strategy and the Environment: A Field of Inquiry Emerges. Oxford University Press. https://doi.org/10.1093/oxfordhb/9780199584451.003.0002

Seddon, J. (2003). Freedom from command and control: a better way to make the work work. Buckingham: Vanguard Consulting Ltd.

Seddon, J. (2008). Systems Thinking in the Public Sector: The Failure of the Reform 
Regime... and a Manifesto for a Better Way. Axminster: Triarchy Press Ltd.

Seghezzo, L. (2009). The five dimensions of sustainability. Environmental Politics, 18(4), 539-556. https://doi.org/10.1080/09644010903063669

Services, etc., value added (\% of GDP) | Data. (n.d.). Retrieved June 13, 2017, from http://data.worldbank.org/indicator/NV.SRV.TETC.ZS?view=map

Sideridis, G., Simos, P., Papanicolaou, A., \& Fletcher, J. (2014). Using Structural Equation Modeling to Assess Functional Connectivity in the Brain: Power and Sample Size Considerations. Educational and Psychological Measurement, 74(5), 733-758. https://doi.org/10.1177/0013164414525397

Smith, T. (2011). Using critical systems thinking to foster an integrated approach to sustainability: A proposal for development practitioners. Environment, Development and Sustainability, 13(1), 1-17. https://doi.org/10.1007/s10668010-9243-y

Sridhar, K., \& Jones, G. (2013). The three fundamental criticisms of the Triple Bottom Line approach: An empirical study to link sustainability reports in companies based in the Asia-Pacific region and TBL shortcomings. Asian Journal of Business Ethics, 2(1), 91-111. https://doi.org/10.1007/s13520-012-0019-3

Starik, M., \& Kanashiro, P. (2013). Toward a theory of sustainability management: Uncovering and integrating the nearly obvious. Organization \& Environment, 26(1), 7-30. https://doi.org/10.1177/1086026612474958

Terpstra, M., \& Verbeeten, F. H. M. (2014). Customer satisfaction: Cost driver or value driver? Empirical evidence from the financial services industry. European Management Journal, 32(3), 499-508. https://doi.org/10.1016/j.emj.2013.07.001

Trevisan, L., Lelah, A., \& Brissaud, D. (2012). Service Delivery and Co-Creation to 
support Value and Sustainability in PSS design. International Conference on Through-Life Engineering Services, 1-8.

Vickery, S. K., Jayaram, J., Droge, C., \& Calantone, R. (2003). The effects of an integrative supply chain strategy on customer service and financial performance: an analysis of direct versus indirect relationships. Journal of Operations Management, 21(5), 523-539. https://doi.org/10.1016/j.jom.2003.02.002

von Geibler, J., Liedtke, C., Wallbaum, H., \& Schaller, S. (2006). Accounting for the social dimension of sustainability: Experiences from the biotechnology industry. Business Strategy and the Environment, 15(5), 334-346. https://doi.org/10.1002/bse.540

Waller, M. A., Fawcett, S. E., \& Johnson, J. L. (2015). The Luxury Paradox: How Systems Thinking and Supply Chain Collaboration Can Bring Sustainability Into Mainstream Practice. Journal of Business Logistics, 36(4), 303-305. https://doi.org/10.1111/jbl.12110

Walker, B., \& Salt, D. (2006). Resilience Thinking, first ed. Washington: Island Press. Wang, H. (2017). Determinants of consumers' purchase behaviour towards green brands. The Service Industries Journal, 37(13-14), 896-918.

Wang, Y., \& Berens, G. (2015). The Impact of Four Types of Corporate Social Performance on Reputation and Financial Performance. Journal of Business Ethics, 131(2), 337-359. https://doi.org/10.1007/s10551-014-2280-y

Whiteman, G., Walker, B., \& Perego, P. (2013). Planetary Boundaries: Ecological Foundations for Corporate Sustainability. Journal of Management Studies, 50(2), 307-336. https://doi.org/10.1111/j.1467-6486.2012.01073.x

Williams, A., Kennedy, S., Philipp, F., \& Whiteman, G. (2017). Systems thinking: A 
review of sustainability management research. Journal of Cleaner Production, 148, 866-881. https://doi.org/10.1016/j.jclepro.2017.02.002

Winn, M. I., \& Pogutz, S. (2013). Business, Ecosystems, and Biodiversity: New Horizons for Management Research. Org. Environ, 26(2), 203-229.

Wong, E. M., Ormiston, M. E., \& Tetlock, P. E. (2011). The Effects of Top Management Team Integrative Complexity and Decentralized Decision Making on Corporate Social Performance. Academy of Management Journal, 54(6), 1207-1228. https://doi.org/10.5465/amj.2008.0762

Yeung, M. C. H., \& Ennew, C. T. (2001). Measuring the impact of customer satisfaction on profitability: A sectoral analysis. Journal of Targeting, Measurement and $\begin{array}{llll}\text { Analysis } & \text { for } & \text { Marketing, } & \text { 106-116. }\end{array}$ https://doi.org/10.1057/palgrave.jt.5740038

Zhang, J. J., Joglekar, N., \& Verma, R. (2012). Pushing the frontier of sustainable service operations management. Journal of Service Management, 23(3), 377-399. https://doi.org/10.1108/09564231211248462 
Table 1- Demographics of the sample.

\begin{tabular}{|l|l|l|}
\hline Characteristic & Alternatives & $\begin{array}{l}\text { Percentage } \\
\text { (\%) }\end{array}$ \\
\hline \multirow{4}{*}{ Job title } & General Director & 4.2 \\
\cline { 2 - 3 } & Operations manager & 64.2 \\
\cline { 2 - 3 } & Systems thinking team leader & 9.5 \\
\cline { 2 - 3 } & $\begin{array}{l}\text { Responsible for sustainability } \\
\text { development }\end{array}$ & 22.1 \\
\hline \multirow{4}{*}{$\begin{array}{l}\text { Number of employees } \\
\text { (Size) }\end{array}$} & $10-49$ & 13.7 \\
\cline { 2 - 3 } & $50-249$ & 42.1 \\
\cline { 2 - 3 } $\begin{array}{l}\text { Number of years of } \\
\text { systems thinking redesign }\end{array}$ & More than 250 & 44.2 \\
\cline { 2 - 3 } & Less than 3 years & 2.1 \\
\cline { 2 - 3 } & 3- less than 5 & 29.5 \\
\cline { 2 - 3 } & 5-less than 7 & 36.8 \\
\cline { 2 - 3 } & 7 years and above & 31.6 \\
\hline
\end{tabular}

Table 2- Results of CFA

\begin{tabular}{|c|c|c|c|c|c|c|c|c|}
\hline Construct & Items & $\begin{array}{l}\text { Factor } \\
\text { loading }\end{array}$ & $\begin{array}{l}\text { t- } \\
\text { values }\end{array}$ & SE & Median & Mode & Mean & SD \\
\hline \multirow[t]{11}{*}{$\begin{array}{l}\text { Systems } \\
\text { thinking }\end{array}$} & $\begin{array}{l}\text { Collecting clean } \\
\text { information }\end{array}$ & 0.82 & 9.53 & 0.119 & 4 & 4 & 4.07 & 0.890 \\
\hline & $\begin{array}{l}\text { Reduced repeated } \\
\text { customer } \\
\text { contacts/visits. }\end{array}$ & 0.76 & 8.57 & 0.114 & 4 & 4 & 3.83 & 0.895 \\
\hline & $\begin{array}{lr}\text { Matching } & \text { and } \\
\text { predicting } & \text { customer } \\
\text { demands } & \\
\end{array}$ & 0.77 & 8.66 & 0.122 & 4 & 4 & 3.59 & 0.962 \\
\hline & $\begin{array}{l}\text { Increased customer } \\
\text { satisfaction }\end{array}$ & 0.83 & 9.65 & 0.093 & 4 & 4 & 4.18 & 0.758 \\
\hline & $\begin{array}{l}\text { Reduced number of } \\
\text { customer complaints }\end{array}$ & 0.83 & 9.71 & 0.103 & 4 & 4 & 3.53 & 0.836 \\
\hline & $\begin{array}{l}\text { Improved employee } \\
\text { satisfaction }\end{array}$ & 0.81 & 9.33 & 0.101 & 4 & 4 & 4.22 & 0.814 \\
\hline & $\begin{array}{l}\text { Improved } \\
\text { relationships between } \\
\text { employees }\end{array}$ & 0.78 & 8.93 & 0.106 & 4 & 4 & 3.89 & 0.844 \\
\hline & $\begin{array}{l}\text { Improved team } \\
\text { working, learning and } \\
\text { self-development }\end{array}$ & 0.76 & 8.54 & 0.120 & 4 & 4 & 3.47 & 0.944 \\
\hline & $\begin{array}{l}\text { Improved } \\
\text { communication with } \\
\text { other departments }\end{array}$ & 0.77 & 8.65 & 0.109 & 4 & 4 & 3.53 & 0.861 \\
\hline & $\begin{array}{l}\text { Better investment in } \\
\text { employees' time }\end{array}$ & 0.71 & 7.85 & 0.119 & 4 & 4 & 3.74 & 0.913 \\
\hline & Reduction of failure & 0.81 & 10.64 & 0.114 & 5 & 5 & 4.33 & 0.856 \\
\hline
\end{tabular}




\begin{tabular}{|c|c|c|c|c|c|c|c|c|}
\hline & demands & & & & & & & \\
\hline \multirow[t]{3}{*}{$\begin{array}{l}\text { Environmental } \\
\text { performance }\end{array}$} & $\begin{array}{ll}\text { Waste } & \text { reduction } \\
\text { practices } & \end{array}$ & 0.85 & 11.45 & 0.075 & 4 & 4 & 4.04 & 0.886 \\
\hline & $\begin{array}{l}\text { Reduction of energy } \\
\text { use }\end{array}$ & 0.85 & 11.45 & 0.081 & 3 & 3 & 3.08 & 0.964 \\
\hline & $\begin{array}{l}\text { Reduced } \\
\text { organizational } \\
\text { resources } \\
\text { consumption }\end{array}$ & 0.88 & 12.76 & 0.071 & 4 & 4 & 3.86 & 1.006 \\
\hline \multirow[t]{5}{*}{$\begin{array}{l}\text { Social } \\
\text { performance }\end{array}$} & $\begin{array}{l}\text { Increased customer } \\
\text { loyalty }\end{array}$ & 0.85 & 10.77 & 0.092 & 4 & 4 & 4.03 & 0.831 \\
\hline & $\begin{array}{l}\text { Improved employee } \\
\text { retention }\end{array}$ & 0.77 & 9.10 & 0.114 & 4 & 4 & 3.58 & 0.963 \\
\hline & $\begin{array}{l}\text { Improved employee } \\
\text { motivation }\end{array}$ & 0.88 & 11.60 & 0.096 & 4 & 5 & 4.21 & 0.898 \\
\hline & $\begin{array}{l}\text { Improved manager- } \\
\text { employee } \\
\text { relationships }\end{array}$ & 0.85 & 10.89 & 0.099 & 4 & 4 & 3.61 & 0.903 \\
\hline & $\begin{array}{l}\text { Improved } \\
\text { departmental } \\
\text { collaboration }\end{array}$ & 0.85 & 13.25 & 0.079 & 4 & 4 & 3.42 & 0.833 \\
\hline \multirow[t]{4}{*}{$\begin{array}{l}\text { Economic } \\
\text { performance }\end{array}$} & $\begin{array}{l}\text { Employees' } \\
\text { productivity increase }\end{array}$ & 0.77 & 9.00 & 0.108 & 4 & 4 & 3.82 & 0.838 \\
\hline & $\begin{array}{l}\text { Reduction of cost of } \\
\text { duplicated processes }\end{array}$ & 0.86 & 10.63 & 0.121 & 4 & 4 & 4.01 & 0.995 \\
\hline & $\begin{array}{l}\text { Reduction of costs } \\
\text { associated } \\
\text { customer complaints }\end{array}$ & 0.88 & 11.12 & 0.120 & 4 & 4 & 3.46 & 1.009 \\
\hline & profit increase & 0.84 & 14.43 & 0.91 & 3 & 4 & 3.23 & 0.792 \\
\hline \multirow[t]{3}{*}{ TMS } & \begin{tabular}{l} 
Top management has \\
ethical responsibility \\
to sustainability \\
\multicolumn{2}{l}{ development } \\
\end{tabular} & 0.87 & 11.44 & 0.073 & 4 & 4 & 4.05 & 0.817 \\
\hline & $\begin{array}{ll}\text { Top management } & \text { is } \\
\text { interested } & \text { in } \\
\text { implementation of } \\
\text { initiatives to improve } \\
\text { sustainability }\end{array}$ & 0.92 & 12.77 & 0.083 & 4 & 4 & 3.51 & 0.977 \\
\hline & $\begin{array}{l}\text { Top management } \\
\text { aims that the firm } \\
\text { become a leader in } \\
\text { relation } \\
\text { sustainability } \\
\text { development }\end{array}$ & 0.87 & 10.63 & 0.077 & 3 & 3 & 3.05 & 0.972 \\
\hline
\end{tabular}


Table 3-Results of discriminant and construct validity

\begin{tabular}{|l|l|l|}
\hline Construct & AVE & CR \\
\hline Systems thinking & 0.620 & 0.947 \\
\hline Environmental performance & 0.74 & 0.895 \\
\hline Social performance & 0.707 & 0.923 \\
\hline Economic performance & 0.703 & 0.904 \\
\hline TMS & 0.787 & 0.750 \\
\hline
\end{tabular}

Table 4- Results for testing hypotheses of the research.

\begin{tabular}{|c|c|c|c|c|c|c|}
\hline Hypothesis & Description & $\begin{array}{l}\text { Estimat } \\
\mathrm{e}\end{array}$ & S.E. & C.R. & $\mathrm{P}$ & Result \\
\hline H1 & $\begin{array}{l}\text { The adoption of systems thinking } \\
\text { approach in service operations } \\
\text { design is positively related to the } \\
\text { environmental performance of } \\
\text { service organisations. }\end{array}$ & 0.977 & 0.109 & 8.982 & $0.000 * *$ & Supported \\
\hline $\mathrm{H} 2$ & $\begin{array}{l}\text { The adoption of systems thinking } \\
\text { approach in service operations } \\
\text { design is positively related to } \\
\text { improved social benefits to } \\
\text { customers and employees. }\end{array}$ & 0.834 & 0.210 & 3.963 & $0.000 * *$ & Supported \\
\hline H3 & $\begin{array}{l}\text { The adoption of systems thinking } \\
\text { approach in service operations } \\
\text { design is positively related to the } \\
\text { economic performance of service } \\
\text { organisations. }\end{array}$ & -0.430 & 0.421 & -1.020 & 0.308 & Rejected \\
\hline $\mathrm{H} 4$ & \begin{tabular}{|l|} 
Environmental performance of \\
service organisations is positively \\
associated with creating social \\
benefits to employees and customers.
\end{tabular} & -0.045 & 0.188 & -0.237 & 0.812 & Rejected \\
\hline H5 & \begin{tabular}{|l} 
Environmental performance of \\
service organisations is positively \\
$\begin{array}{l}\text { associated } \\
\text { performance. }\end{array}$
\end{tabular} & 0.501 & 0.218 & 2.302 & $0.021 * *$ & Supported \\
\hline H6 & $\begin{array}{l}\text { Social benefits to employees and } \\
\text { customers are positively associated } \\
\text { with economic performance of } \\
\text { service organisations. }\end{array}$ & 0.601 & 0.366 & 2.141 & $0.048 * *$ & Supported \\
\hline
\end{tabular}

$* *$ significant at $\mathrm{p}<0.05$ 


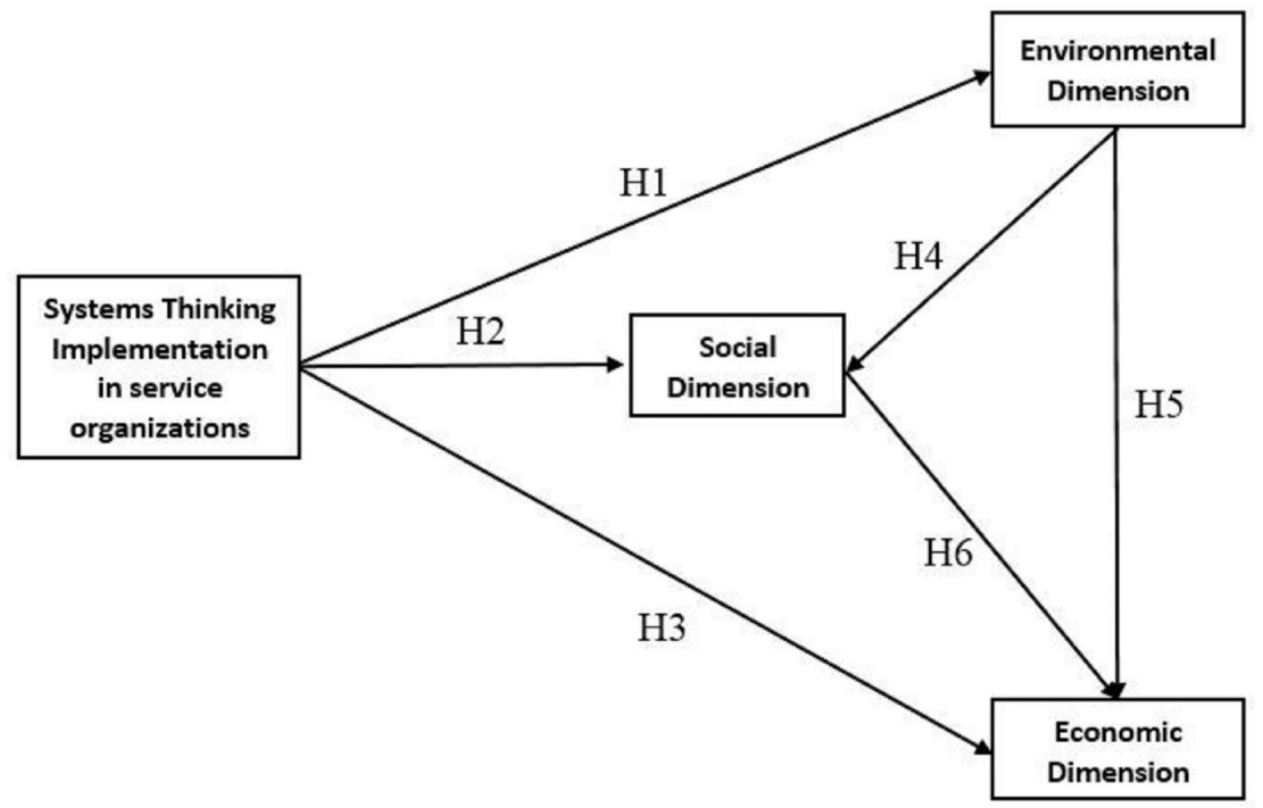

Figure 1. A conceptual research model linking systems thinking to TBL of sustainability

\section{Sample \%}

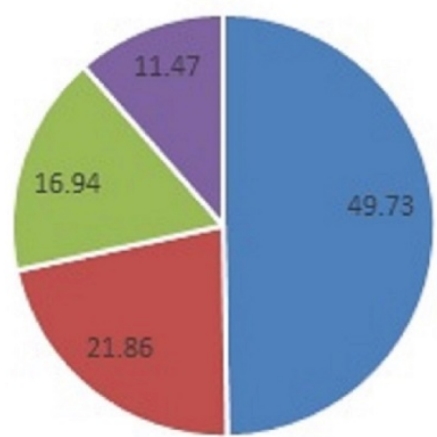

- Logistics of housing repair and maintenance a Insur ance services

" Financial services

- IT support services

Figure 2- Distribution of participating organizations according to industry type 


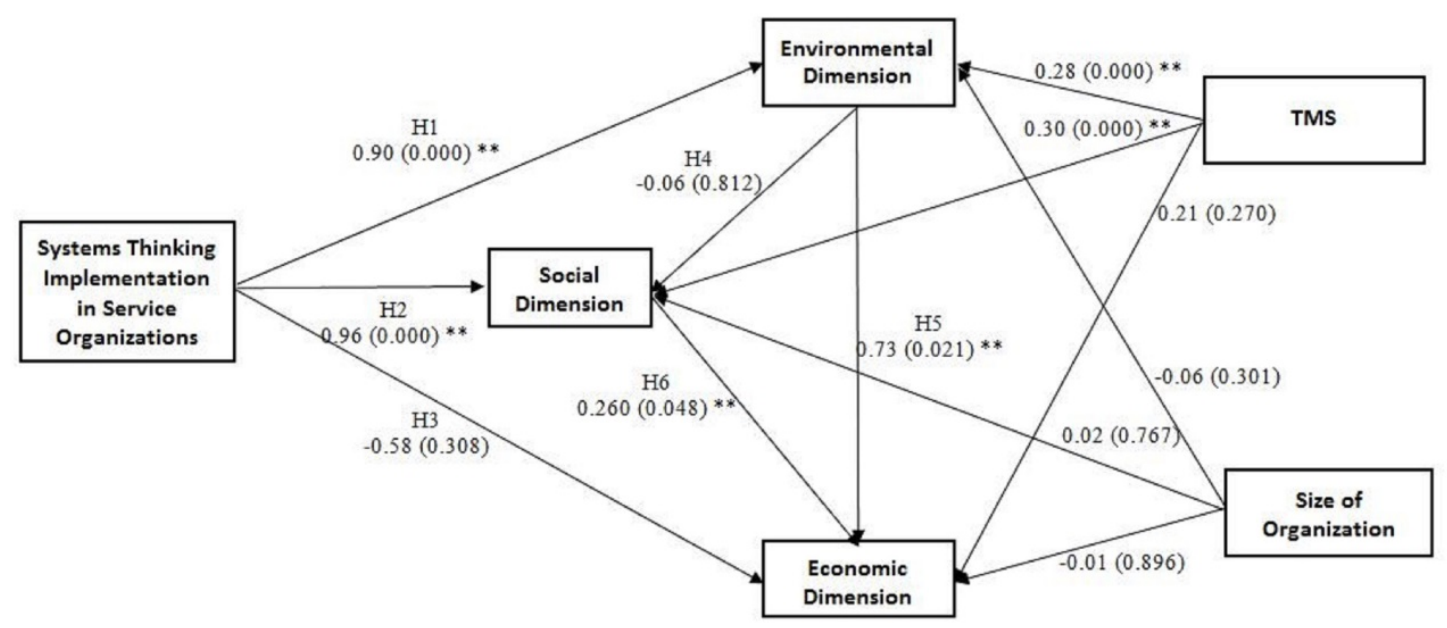

Figure 3- Results of the SEM with standardized regression weights. 